
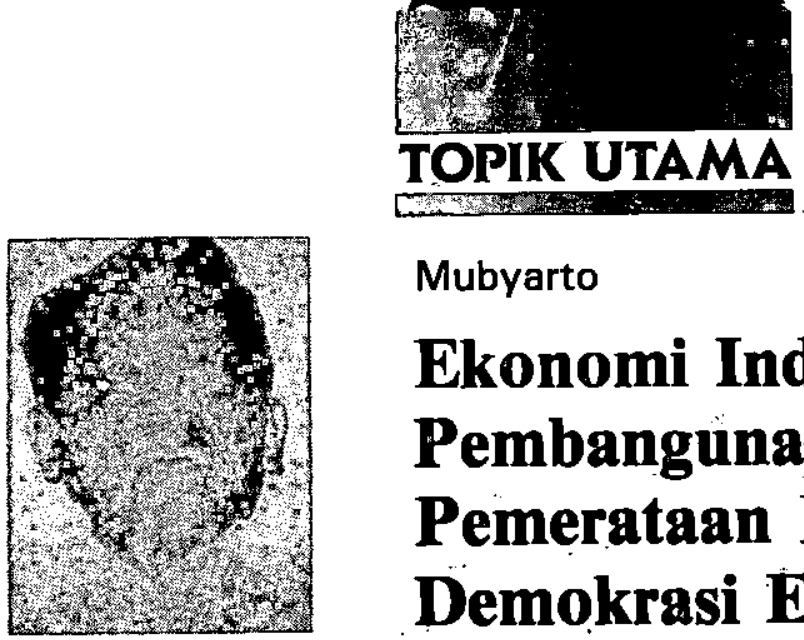

\title{
Mubyarto \\ Ekonomi Indonesia : \\ Pembangunan dengan \\ Pemerataan Menuju \\ Demokrasi Ekonomi
}

\section{Pendahuluan}

Setelah mengalami masa penjajahan 350 tahun, masa kemerdekaan (kembali) bangsa Indonesia sejak 1945 telah mengalami pasang surut "sistem" ekonomi yang berubah-ubah sebagai berikut :

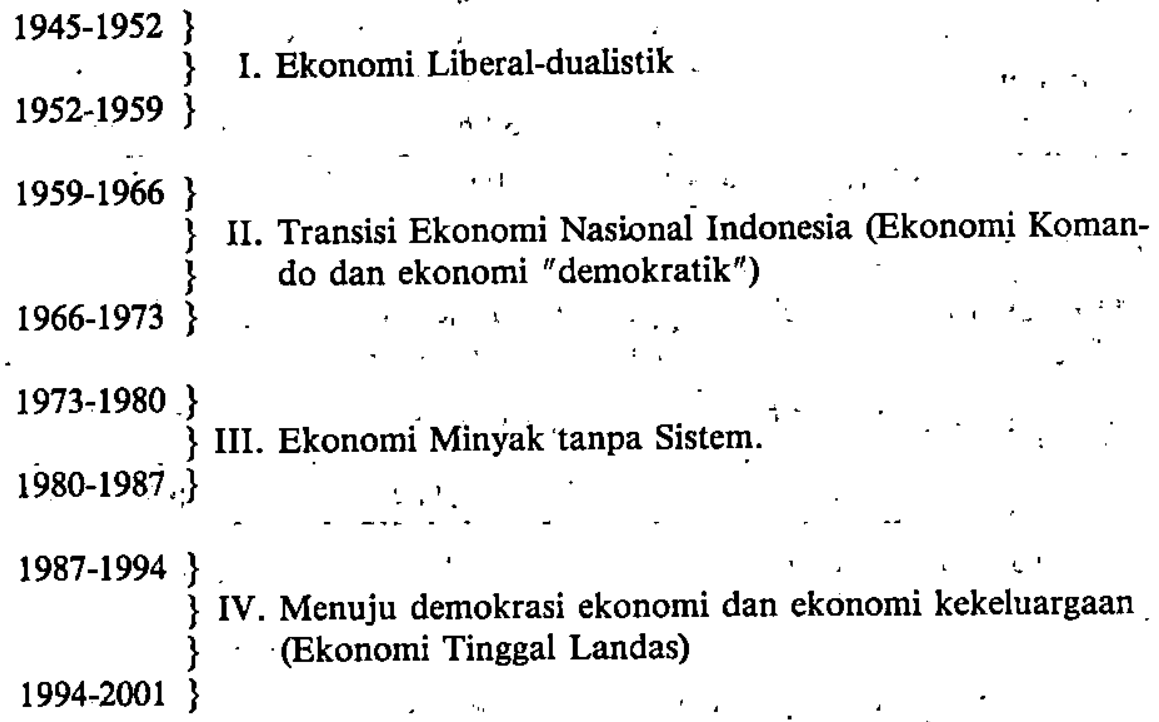

II. Transisi Ekonomi Nasional Indonesia (Ekonomi Komando dan ekonomi "demokratik")

$1966-1973$

$1973-1980$.

$1980-1987 . ;$

III. Ekonomi Minyak tanpa Sistem.

1987-1994 \}

1994-2001

IV. Menuju demokrasi ekonomi dan ekonomi kekeluargaan

\}. (Ekonomi Tinggal Landas)

Dewasa ini pelbagai pertimbangan ekonomi dengan aneka permasalahannya akan membawa kita (Insya Allah) pada sistem ekonomi yang demokratis berasas kekeluargaan, di mana Pancasila mempedomani setiäp pelaku ekonomi dalam perilaku produksi, distribusi, dan konsumsi, menuju terwujudnya keadilan sosial bagi seluruh rakyat Indonesia. Itulah ekonomi "tinggal landas".

Sejak Orde Baru, ekonomi Indonesia telah mengalami banyak kemajuan terutama. diukur dalam peningkatan kesejahteraan materiil. Pertumbuhan ekonomi Indonesia adalah cukup mengesankan sebagai berikut : 
Tabel 1 Pertumbuhan Ekonomi Selama 4 Pelita

Pelita I

Pelita II

Pelita III

Pelita IV
$8,4 \%$ per tahun

$7,2 \%$ per tahun

$6,1 \%$ per tahun

$5,1 \%$ per tahun

Sumber : BPS.

Dalam pada itu selama 4 Pelita tersebut telah terjadi perubahan sturktur ekonomi yaitu pergeseran peranan sektor-sektor ekonomi dalam keseluruhan Produk Domestik Bruto (PDB) sebagai berikut :

Tabel 2 Perubahan Struktur Ekonomi Indonesia

\begin{tabular}{l|c|c|c|c}
\hline Sektor Ekonomi & Pelita I & Pelita II & Pelita III & Pelita IV \\
\hline Pertanian & 40,1 & 32,6 & 29,9 & 21,1 \\
Pertambangan & 12,3 & 11,0 & 7,5 & 16,0 \\
Industri & 9,6 & 12,9 & 5,1 & 18,4 \\
B ang u n a n & 3,9 & 5,5 & 6,3 & 5,1 \\
Transpor/komunikasi & 3,8 & 5,4 & 5,9 & 5,2 \\
lain-lain & 30,3 & 32,6 & 25,3 & 34,2 \\
\hline \multicolumn{1}{c|}{ Total PDB } & 100,0 & 100,0 & 100,0 & 100,0 \\
\hline
\end{tabular}

Sumber : BPS.

Ditinjau dari segi pengeluargan juga telah terjadi perubahan struktural yang positif di mana terlihat ada kenaikan persentase investasi yang cukup berarti.

Tabel 3 Investasi Dari PDB Total (dalam persen)

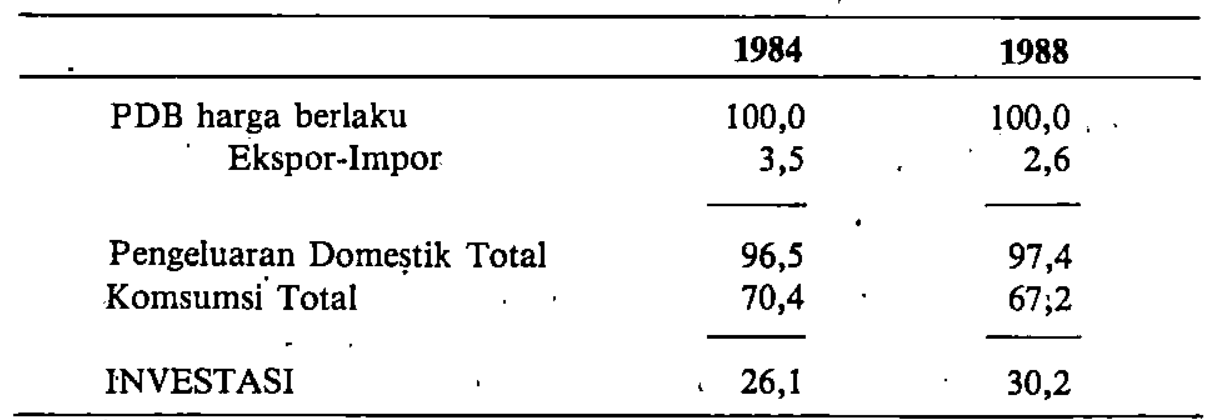

Sumber : BPS.

Namun pertumbuhan ekonomi yang relatif baik, yang berarti meningkatkan kesejahteraan materiil, tidak selalu berarti secara otomatis terwujudnya keadilan sosial bagi seluruh rakyat. Untuk tercapainya keadilan sosial, masih perlu 
dipenuhi adanya pemerataan yaitu distribusi hasil pertumbuhan ekonomi secara adil dan merata.

Maka, agar tercapai kesejahteraan sosial ada tiga ukuran lain yang perlu' diperhatikan yaitu tingkat kemiskinan, tingkat pengangguran, dan tingkat ketimpangan dalam distribusi pendapatan dan kekayaan nasional.

Dalam ukuran pengurangan tingkat kemiskinan, pembangunan ekonomi kita telah menunjukkan banyak kemajuan, tetapi dalam penyediaan kesempatan kerja hasilnya belum melegakan. Dan masalah paling gawat kita hadapi dalam hal ketimpangan distribusi pendapatan dan kekayaan yang sangat merisaukan.

Kapitalisme, Sosialisme, dan Pancasilaisme.

Presiden Soeharto yang dalam "Otobiografi" (1989) menganjurkan agar kita tak perlu merasa was-was melihat perkembangan "dinasti ekonomi" dan konglomerat yang pesat, ternyata sudah mengambil langkah kongkrit untuk mengatasi kesenjangan ekonomi dan sosial yang nampak semakin memprihatinkan. Dalam beberapa kesempatan Presiden memang mengkhawatirkan bahwa jika tidak diambil langkah-langkah kongkrit dalam upaya pemerataan maka bukan tidak mungkin akan terjadi kecemburuan sosial serta gejolak-gejolak sosial.

Untuk "mengoreksi" perkembangan pembangunan ekonomi dewasa ini, yang menunjukkan kesenjangan yang besar, sering diajukan dua alternatif ekstrim yaitu (1) mempertahankan sistem ekonomi dan sosial yang berjalan dewasa ini, (yang menomorsatukan pertumbuhan) atau (2) merombak sistem dan menggantinya dengan sistem ekonomi dan sosial lain yang secara jelas menomorsatukan pemerataan.

Apabila alternatifnya diberikan secara dikotomi yang demikian, lebih-lebih dengan menunjukkan pada pengalaman sistem-sistem ekonomi besar di dunia yang sedang berubah secara mendasar (kapitalisme dan sosialisme), terutama di Eropa Timur, maka tentu saja orang akan lebih aman memilih alternatif pertama, yang sudah menunjukkan bukti-bukti kongkrit peningkatan kesejahteraan materiil meskipun belum benar-benar merata. Namun demikian, memilih alternatif pertama "tanpa reserve" juga tidak sehat, karena justru sistem ekonomi inilah yang kini dianggap banyak menimbulkan ekses-ekses kesenjangan sosial yang serius. Kelemahan (cacat) sistem ekonomi pasar yang "liberal" adalah mudah menjurus ke praktek monopoli, dan ketidak berdayaannya untuk mengatasi pengangguran.

Apabila kita percaya bahwa ideologi Pancasila memiliki "sesuatu" yang lebih dari sekedar "bukan ini bukan itu", pastilah kita tidak perlu terkurung pada hanya 2 alternatif ekstrim tersebut. Bahwa Orde Baru adalah anti-komunis berarti Indonesia tidak mungkin menghendaki pemerataan gaya Uni Soviet atau RRC. Tetapi di pihak lain, apabila kita menyadari bahwa sistem ekonomi yang berjalan sekarang memang diakui sudah bisa secara nyata meningkatkan kemakmuran, 
tetapi belum adil dan merata, tentulah perlu dipikirkan kebijaksanaan dan program-program pemerataan untuk "mengoreksinya", baik dalam peningkatan pemerataan kesempatan berusaha maupun kesempatan bekerja. Programprogram delapan jalur pemerataan yang sudah berumur 2 Pelita memberikan garis-garis besar bagaimana cara-cara meningkatkan pemerataan, yaitu :

1. Pemerataan pemenuhan kebutuhan pokok rakyat banyak khususnya pangan, sandang dan perumahan;

2. Pemerataan kesempatan memperoleh pendidikan dan pelayanan kesehatan;

3. Pemerataan pembagian pendapatan;

4. Pemerataan kesempatan kerja;

5. Pemerataan kesempatan berusaha;

6. Pemerataan kesempatan berpartisipasi dalam pembangunan khususnya bagi generasi muda dan kaum wanita;

7. Pemerataan penyebaran pembangunan di seluruh tanah air;

8. Pemerataan kesempatan memperoleh keadilan.

Dengan penjabaran delapan jalur pemerataan ini pemerintah bertekad melaksanakan berbagai kebijaksanaan yang tegas-tegas bertujuan memeratakan konsumsi dan kemampuan mengk'onsumsi, serta kesempatan-kesempatan untuk bekerja dan berusaha. Sasaran berbagai kebijaksanaan ini adalah untuk menciutkan perbedaan pendapat, kekayaan dan tingkat hidup pada umumnya.

Yang kiranya masih perlu menjadi pembahasan adalah, apakah-sekali lagi upaya-upaya pemerataan itu sendiri memerlukan cara-cara yang didasarkan atas prinsip keadilan, yang justru dapat mempercepat pencapaian tujuan masyarakat yang adil dan makmur. Berdasar pengalaman pelaksanan setiap program pemerataan (equality), memang menghadapi masalah asas keadilan ini. Setiap pejabat pelaksana atau perumus kebijaksanaan perlu dan patut selalu terpanggil menggunakan rasa keadilan ini dalam mempertimbangkan berbagai kebijaksanaan dan dalam melaksanakan macam-macam program serta proyek-proyek pemerataan.

Landasan teoritis mengenai mutlak perlunya pemerataan sangat kuat dikemukakan oleh tokoh ekonomi J.M. Keynes (1936).

The outstanding faults of the economic society in which we live are its failure to provide for full employment and its arbitrary and inequitable distribution of wealth and incomes. ${ }^{3}$ )

Keynes menolak anggapan bahwa pemerataan akan menghambat pertumbuhan modal, dan pertumbuhan kekayaan, dan jauh dari ketergantungannya pada pengendalian diri orang-orang kaya, pertumbuhan modal bahkan dihambat olehnya.

3. J.M. Keynes, The General Theory, Hal. 372. 
...measure for the redistribution of incomes in a way likely to raise the propensity to consume may prove positively favourable to the growth of capital.

..the growth of wealth so far from being depen-dent in the abstinence of the rich, as is commonly supposed, is more likely to be impeded by it.4)

Melalui ungkapan-ungkapan tersebut Keynes dikenal sebagai tokoh "sosialis" yang "menyelamatkan" kapitalisme.

\section{Kesenjangan Sosial dan Kemajuan Sektor Usaha Swasta.}

Dewasa ini banyak berkembang pemikiran yang cenderung curiga pada dunia bisnis konglomerat, karena kesenjangan yang dirasakan semakin besar memang "terasa" sekali dalam bidang ekonomi, di mana sektor usaha swasta nampak semakin kuat sedangkan peranan usaha-usaha negara dan koperasi relatif ketinggalan. Dalam tabel berikut bisa dilihat data semakin membesarnya peranan usaha-usaha swasta ini dalam industri manufaktur, di mana swasta dan swasta yang berpatungan dengan perusahaan-perusahaan asing meningkat peranannya dari $61,2 \%$ tahun 1975 menjadi $78 \%$ tahun 1983, sedangkan peranan pemerintah menurun secara tajam.

\section{Tabel 4}

Nilai Produksi dan Jumlah Pekerja pada Industri Manufaktur Berdasar Pemilikan, 1975 dan 1983

\begin{tabular}{l|c|c|c|c}
\hline \multirow{2}{*}{ Pemilikan } & \multicolumn{2}{|c|}{1975} & \multicolumn{2}{c}{1983} \\
\cline { 2 - 5 } & $\begin{array}{c}\text { Nilai Produksi } \\
(\%)\end{array}$ & $\begin{array}{c}\text { Pekerja } \\
(\%)\end{array}$ & $\begin{array}{c}\text { Nilai Produksi } \\
(\%)\end{array}$ & $\begin{array}{c}\text { Pekerja } \\
(\%)\end{array}$ \\
\hline Pemerintah & 25,0 & 15,8 & 14,4 & 13,0 \\
Swasta & 50,7 & 74,6 & 56,9 & 74,0 \\
Asing & 10,2 & 2,0 & 1,5 & 1,1 \\
Pemerintah/Swasta & 1,1 & 1,2 & 1,0 & 1,1 \\
Pemerintah/Asing & 2,1 & 0,7 & 4,2 & 1,1 \\
Swasta/Asing & 10,5 & 5,5 & 21,1 & 9,4 \\
Pemerintah/Swasta/ & & & & \\
Asing & 0,4 & 0,2 & 0,1 & 0,3 \\
\hline Total & 100,0 & 100,0 & 100,0 & 100,0 \\
\hline
\end{tabular}

Sumber : Hal Hil, Foreign Investment and Industrialization in Indonesia, Oxford 1988, Hal 20.

Yang juga semakin mèrisaukan rakyat adalah adanya kesan bahwa pemerintah justru lebih sering terlihat "berdiri dibelakang" dunia bisnis besar, karena alasan bahwa merekalah (bisnis besar) yang merupakan pembayar pajak terbesar dan

4. Idem, Hal. 373

UNISIA 9.XI.III.1991 
pada merekalah "pertumbuhan ekonomi" bangsa dan negara dipertaruhkan. Kesan yang demikian pernah terasa cukup "menyakitkan" dalam kasus isu lemak babi dan biskuit beracun di mana konsumen yang lemah harus "mengalah" pada kelompok produsen yang sangat kuat.

Mungkin saja orang mengatakan bahwa sistem ekonomi Indonesia dewasa ini bukan "kapitalis-liberal". Namun dukungan pemerintah pada dunia bisnis besar yang sering terlihat menyolok tidak bisa menghindarkan kesan yang demikian, misalnya dengan cukup banyaknya pengusaha yang leluasa membayar upah di bawah ketentuan upah minimum. Satu survey di Jakarta menunjukkan bahwa dengan pelbagai alasan, antara $41-72 \%$ dari perusahaan benar-benar membayar upah di bawah ketentuan minimum. Dibandingkan negara-negara tetangga memang upah buruh di Indonesia termasuk amat rendah. Dalam pada itu sulit dipahami mengapa pemerintah mendorong dan menganjurkan produsen/ pengusaha membentuk kelompok-kelompok yang disebut asosiasi, tetapi sering menaruh curiga pada kegiatan-kegiatan SPSI atau kelompok-kelompok petani yang menuntut perbaikan upah (atau kesejahteraan).

"Mengantisipasi" perilaku kaum pengusaha (businessman) di kelak kemudian hari, Bapak Ilmu Ekonomi Adam Smith pada tahun 1776 memberikan "landasan teori" tentang potensi adanya semacam "persekongkolan" (conspiracy) di kalangan dunia bisnis terhadap masyarakat banyak.

People of the same trade seldom meet together, even for merriment and diversion, but the conversation ends in a conspiracy against the public or in some contrivance to raise prices. It is impossible indeed to prevent such meetings by any law which either could be executed or would be consistent with liberty and justice. But though the law cannot hinder people of the same trade from sometimes assembling together, it ought to do nothing to facilitate such assemblies; much less to render them-necessary. 6

Apabila sinyalemen Adam Smith ini kita kaitkan dengan pandangan bapakbapak pendiri negara Republik Indonesia, maka kita temukan penjelasan pasal 33 UUD 1945 sebagai berikut :

Perekonomian berdasar atas demokrasi ekonomi, kemakmuran bagi semua orang, sebab itu cabang-cabang produksi yang penting bagi negara dan menguasai hidup orang banyak harus dikuasai oleh negara. Kalau tidak, tampuk produksi jatuh ke tangan orang-seorang yang berkuasa dan rakyat yang banyak ditindasnya.

\section{Konglomerat vs Koperasi}

Dalam pada itu kalangan usaha-usaha swasta besar kini muncul "kecurigaan" jenis baru khususnya terhadap program-program pemerataan yang semakin gencar. Kecurigaan ini misalnya berupa kekhawatiran bahwa dunia bisnis swasta yang sudah nyata-nyata semakin kuat dewasa ini justru akan "ditekan" kembali, yang akhirnya hanya akan sekali lagi mengorbankan sasaran pertumbuhan

6. Adam Smith, Wealth of Nations, op.cit, Book I, Ch. X 
ekonomi tinggi yang sangat diperlukan untuk "memelihara momentum pembangunan".

Pandangan bahwa pengembangan koperasi dan usaha kecil akan berarti "mengerem" pertumbuhan bisnis swasta besar, dan mengerem pertumbuhan ekonomi, selalu merupakan senjata ampuh untuk "menyangsikan" upaya-upaya pemerataan melalui pengembangan sistem kekeluargaan. Kita seharusnya tidak perlu khawatir bahwa pengembangan ekonomi rakyat kecil, baik yang berkelompok dalam koperasi maupun yang bersaing secara bebas dalam sektor informal, akan berakibat menurunkan daya tahan dan "daya saing" ekonomi bangsa, dan mengganggu pertumbuhan ekonomi yang tinggi. Bahkan sebaliknya perbaikan ekonomi rakyat dan daya beli rakyat akan besar sumbangannya pada peningkatan ketahanan ekonomi bangsa dan negara.

Bahwa koperasi Indonesia dewasa ini belum berkembang sebenarnya bukanlah semata-mata karena modalnya kurang, atau manajemennya kurang handal, tetapi lebih banyak disebabkan "kekeliruan" konsep dan teori yang mendasari kebijaksanaan pengembangannya. Pemerintah selama ini sangat terkesan menganut paham bahwa koperasi adalah badan usaha dan semata-mata sebagai badan usaha, dan bukan sebagai perkumpulan orang yang mempunyai kepentingan ekonomi yang sama, atau sebagai gerakan ekonomi rakyat sebagaimana tercantum jelas dalam GBHN. Pandangan yang tidak tepat seperti ini kiranya harus ditinjau kembali. Di pihak lain pemerintah dalam hal KUD juga keliru menganggap bahwa koperasi adalah alat pemerintah untuk melaksanakan program-program kesejahteraan. Selama pemerintah tidak mengoreksi kekeliruan konsepsual ini, kiranya akan sulit mengembangkan lembaga koperasi sebagai gerakan ekonomi rakyat yang merupakan sokoguru ekonomi nasional. Rumusan GBHN kita yang cukup sederhana memang masih sering dibaca secara keliru dengan menonjolkan koperasi sebagai badan usaha yang (selalu) mengejar laba atau wadah sosial yang (selalu) bisa memberikan kesejahteraan kepada anggota atau bahkan sering diharapkan juga bagi nonanggota. Yang selalu benar adalah bahwa para anggota koperasilah yang mengejar laba, sedangkan koperasi membantu anggota dalam meningkatkan laba para anggota.

Tentang koperasi dan peranannya dalam perekonomian Indonesia ini, pandangan masyarakat termasuk pemerintah dan para pakar memang diakui masih sering berbeda-beda. Ada pendapat bahwa bagaimanapun koperasi harus dianggap sebagai badan usaha yang mengejar laba seperti lembaga-lembaga (organisasi) ekonomi lain-lain, karena kalau tidak demikian ia pasti akan "tergusur" dalam kancah persaingan bebas. Juga diasumsikan bahwa anggota koperasi pasti hanya tertarik pada organisasi yang bisa memberikan manfaat (keuntungan) kepadanya. Laba (SHU) menurut anggapan ini adalah satu-satunya "daya tarik" koperasi. 
Dalam pada itu pendapat lain yang sama kuatnya justru mengkhawatirkan penekanan pada asumsi pengejaran laba ini. Apabila koperasi sebagai badan usaha (yang cenderung "bebas" dari anggotanya) mengejar labanya sendiri, sehingga untuk itu banyak mengembangkan "bisnis" dengan non-anggota, berdasarkan pengalaman justru ia akan "menjauhkan" hubungan ekonomi dengan anggota. Maka prosesnya akan berjalan sedemikian rupa sehingga partisipasi anggota dalam kegiatan koperasi menjadi marjinal; dan koperasi sebagai badan usaha semakin tidak berorientasi pada anggota dan pada gilirannya tidak akan ada keharusan bagi koperasi untuk melayani anggota-anggotanya.

Maka himbauan bahwa saham perusahaan sebaiknya hanya "dijual" kepada koperasi, dan bukan kepada anggota atau (oknum) pengurus, mencerminkan konsep pertama tersebut. Ada kemungkinan, memang, bahwa hal ini didasarkan pada "pengalaman" lain yang cenderung mencurigai oknum-oknum pengurus yang "mengejar KUD" (ketua untung dulu), sehingga untuk menghindarkan ini perlu diatur agar pembeli saham adalah lembaga koperasi, bukan anggota atau pengurus. Namun demikian keharusan adanya partisipasi anggota secara perorangan dalam organisasi koperasi mutlak perlu diperhatikan. Inilah yang sudah $\mathrm{di}^{\prime \prime}$ koreksi" dalam kasus PT Teh Nusamba di mana 70 persen saham yang dijual diperuntukkan bagi UUPT (unit usaha petani teh), dan hanya 15 persen untuk KUD dan 15 persen untuk koperasi karyawan (Kompas, 30 April 1990).

Dalam hubungan ini perlu diingatkan lagi bahwa yang perlu memikirkan pengalihan pemilikan (saham) perusahaan kepada koperasi bukanlah hanya perusahaan-perusahaan swasta saja tetapi juga usaha-usaha negara (BUMN). Ini disebut jelas dalam GBHN 1988 sebagai berikut :

Dalam rangka perwujudan tatanan kehidupan ekonomi yang adil, koperasi perlu diberi kesempatan lebih luas untuk turut serta memiliki usaha-usaha swasta maupun negera.

Maka oleh sebab itu BUMN yang mengelola pabrik-pabrik gula di Jawa misalnya, perlu secara cepat dan sigap memulai pemikiran serius ke arah sana. Asumsi dasarnya adalah bahwa keikutsertaan dalam pemilikan pabrik-pabrik gula oleh petani TRI akan meningkatkan semangat kemitraan kerja, dan pada gilirannya akan menggairahkan semangat kerja dan berusaha, yang sekaligus akan mengarah pada terciptanya tatanan kehidupan ekonomi yang adil dan merata..

Dalam pada itu BUMN-BUMN sekarang ini nampak kurang tanggap terhadap himbauan Presiden, dan hanya sekedar menekankan pada program-program anak-bapak angkat, kiranya hasilnya akan lama sekali. KADIN yang sekarang sudah secara hukum (legal) menjadi warga usaha (ekonomi) nasional (BUMN, Swasta, dan Koperasi) harus berani mengambil langkah-langkah nyata untuk melaksanakan himbauan Presiden tersebut. Namun pegangan segala tindakan nyata ini adalah jelas; yaitu menghasilkan kemitraan kerja yang saling menguntungkan antara ketiganya. 
Masalah yang menjadi cukup mendasar adalah pertanyaan perlu tidaknya proses dan metoda pengalihan saham perusahaan-perusahaan swasta dan BUMN kepada koperasi diatur atau dikukuhkan secara hukum (legalisasi atau legislation). Tentang hal ini jelas ada pula perbedaan pendapat yang. sama-sama kuat alasannya. Pertama, dalam era deregulasi yang sedang digalakkan, perlu dihindari segala "aturan baru" yang sifatnya mengurangi kebebasan berusaha. Khususnya perusahaan-perusahaan asing, atau yang berpatungan dengan perusahaanperusahaan asing, memang mulai mengkhawatirkan hal ini, sehingga sudah diingatkan kemungkinan adanya "capital flight" apabila himbauan ini menjadi kebijaksanaan yang "dipaksakan".

Dalam pada itu pengalihan saham kepada koperasi ini merupakan "pelaksanan" GBHN dalam rangka pewujudan tatanan kehidupan ekonomi yang adil, maka ia memang harus dianggap sebagai isyarat yang cukup kuat dasardasar hukumnya. Yang pasti, demi kepastian hukum, ia justru perlu diatur secara hukum. Apabila karena alasan-alasan ekonomis kita menghindari pengaturan secara hukum, maka bisa diduga hasilnya pun tidak akan bisa diperkirakan secara pasti.

\section{Penutup}

Masalah yang kiranya harus dianggap paling strategis dalam mengurangi kesenjangan ekonomi dan sosial di negara kita dewasa ini adalah "penjabaran" pengertian demokrasi ekonomi, dan ekonomi kekeluargaan. Demokrasi ekonomi menghendaki bahwa seluruh rakyat dan kekuatan ekonomi harus ikut serta dalam proses pengambilan putusan-putusan ekonomi (produksi), sedangkan ekonomi kekeluargaan nampaknya lebih menekankan pada hasil (distribusi) pelaksanaan demokrasi (bangsa) Indonesia dan kerakyatan untuk mewujudkan keadilan sosial bagi seluruh rakyat, jelas mengandung pengertian perlunya ada demokrasi (kerakyatan) dalam segala bidang mencakup ekonomi, politik, dan hukum. Hanya dengan prinsip demokrasi bisa dicapai kemakmuran yang merata bagi seluruh warga masyarakat, bukạ hanya kemakmuran bagi orang seorang. Demokrasi ekonomi menunjuk pada cara-cara produksi, ekonomi kekeluargaan menunjuk pada hasil (distribusi), dan ekonomi Pancasila menunjukkan pedoman dan asas-asas umum perilaku berekonomi dan berbisnis sehari-hari. 
Lampiran 1

PDRB Termasuk Minyak dan PDRB tanpa Minyak Per Kapita Per Tahun (1984)

\begin{tabular}{|c|c|c|c|c|c|}
\hline \multicolumn{3}{|c|}{ PDRB Termasuk Minyak } & \multicolumn{3}{|c|}{ PDRB Tak Termasuk Minyak } \\
\hline Propinsi & 000 rp & Urutan & Propinsi & 000 rp. & Urutan \\
\hline Kaltim & $3.869,7$ & 1 & DKI Jakarta & $1.191,9$ & 1 \\
\hline Riau & $3.092,7$ & 2 & Kaltim & $1.148,7$ & 2 \\
\hline DI Aceh & $1,694,5$ & 3 & Sumsel & 562,3 & 3 \\
\hline DKI Jakarta & $1.191,5$ & 4 & DI Aceh & 514,7 & 4 \\
\hline Sumsel & 697,3 & 5 & Riau & 510,9 & 5 \\
\hline Irja & 680,3 & 6 & Jatim & 509,4 & 6 \\
\hline Kalteng & 514,0 & 7 & Sumbar & 478,1 & 7 \\
\hline Sumut & 465,5 & 8 & Sumut & 459,0 & 8 \\
\hline Sumbar & 437,1 & 9 & Kalteng & 459,0 & 9 \\
\hline Kalsel & 428,3 & 10 & Bali & 432,6 & 10 \\
\hline Bali & 417,8 & 11 & Kalsel & 395,9 & 11 \\
\hline Maluku & 402,0 & 12 & Sulut & 375,3 & 12 \\
\hline Jatim & 399,3 & 13 & Jateng & 369,3 & 13 \\
\hline Jabar & 384,8 & 14 & DIY & 363,7 & 14 \\
\hline Sulut & 346 & 15 & Jabar & 339,4 & 15 \\
\hline Kalbar & 339,5 & 16 & Bengkulu & 333,3 & 16 \\
\hline Sultra & 333,5 & 17 & Maluku & 319,0 & 17 \\
\hline Jambi & 327,3 & 18 & Sulsel & 318,9 & 18 \\
\hline Bengkulu & 317,8 & 19 & Jambi & 316,9 & 19 \\
\hline Jateng & 309,3 & 20 & Kalbar & 315,3 & 20 \\
\hline Sulsel & 308,2 & 21 & Sultra & 309,2 & 21 \\
\hline DIY & 307,0 & 22 & Sulteng & 284,9 & 22 \\
\hline Sulteng & 286,1 & 23 & NTB & 256,8 & 23 \\
\hline NTB & 213,8 & 24 & Irja & 232,1 & 24 \\
\hline Lampung & 213,5 & 25 & Lampung & 217,9 & 25 \\
\hline NTT & 198,2 & 26 & NTT & 184,4 & 26 \\
\hline
\end{tabular}

Sumber : BPS. 
Lampiran 2

Urutan Pengeluaran Rata-rata Per Kapita Pedesaan 1987 dan 1980

\begin{tabular}{|c|c|c|c|c|c|c|}
\hline \multirow{2}{*}{ Propinsi } & 1987 & 1980 & \multirow{2}{*}{$\begin{array}{l}\text { \%Pertum- } \\
\text { buhan } \\
\text { per thn }\end{array}$} & \multicolumn{2}{|c|}{ Urutan } & \multirow{2}{*}{$\begin{array}{l}\text { \%Penduduk } \\
\text { dibawah } \\
\text { garis ke- } \\
\text { miskinan } \\
\text { (1987) }\end{array}$} \\
\hline & \multicolumn{2}{|c|}{ (000 rp) } & & 1987 & 1980 & \\
\hline 1. DIY & 358,2 & 102,2 & 20,3 & 1 & 12 & 8,89 \\
\hline 2. Sumbar & 319,3 & 124,0 & 14,6 & 2 & 3 & 7,94 \\
\hline 3. Jambi & 298,2 & 123,7 & 12,7 & 3 & 4 & 5,62 \\
\hline 4. Bengkulu & 294,4 & 108,0 & 13,9 & 4 & 9 & 9,99 \\
\hline 5. Sulteng & 269,8 & 99,5 & 14,3 & 5 & 13 & 13,50 \\
\hline 6. NTB & 263,8 & 103,9 & 15,4 & 6 & 11 & 45,25 \\
\hline 7. Sumut & 260,4 & 114,0 & 12,5 & 7 & 7 & 16,54 \\
\hline 8. Jabar & 253,3 & 96,1 & 15,7 & 8 & 15 & 14,08 \\
\hline 9. Jatim & 253,2 & 96,3 & 15,7 & 9 & 14 & 11,58 \\
\hline 10. Kaltim & 245,4 & 84,8 & 14,3 & 10 & 18 & 4,58 \\
\hline 11. Sumsel & 244,6 & 126,1 & 9,9 & 11 & 2 & 7,54 \\
\hline 12. Sulut & 244,0 & 112,2 & 13,0 & 12 & 8 & 10,80 \\
\hline 13. Kalsel & 240,3 & 93,2 & 13,1 & 13 & 16 & 6,01 \\
\hline 14. DI Aceh & 239,7 & 147,2 & 8,7 & 14 & 1 & 3,53 \\
\hline 15. Kalteng & 232,0 & 106,4 & 9,7 & 15 & 10 & 11,58 \\
\hline 16. Bali & 230,3 & 66,4 & 19,2 & 16 & 22 & 18,31 \\
\hline 17. Jateng & 217,7 & 92,3 & 15,8 & 17 & 17 & 15,33 \\
\hline 18. Sultra & 204,6 & 76,3 & 13,1 & 18 & 21 & 31,66 \\
\hline 19. Lampung & 199,9 & 78,6 & 14,6 & 19 & 19 & 25,89 \\
\hline 20. Sulsel & 176,6 & 77,0 & 12,9 & 20 & 20 & 17,78 \\
\hline 21. NTT & 173,4 & 59,1 & 14,9 & 21 & 19 & 49,91 \\
\hline 22. Maluku & 163,9 & 58,3 & 13,1 & 22 & 25 & 10,45 \\
\hline 23. Kalbar & 163,7 & 112,3 & 5,4 & 23 & 5 & 12,25 \\
\hline 24. Riau & 147,7 & 115,8 & 7,7 & 24 & 6 & 17,31 \\
\hline 25. Irjạ & 83,1 & 60,8 & 4,4 & 25 & 23 & 31,98 \\
\hline Indonesia & 231,1 & 97,4 & 19,6 & & & 13,33 \\
\hline
\end{tabular}

Sumber : BPS. 